Volume 4 Issue 2, September 2019: . Copyright @ LamLaj. Faculty of Law, Lambung Mangkurat University, Banjarmasin, South Kalimantan, Indonesia. ISSN: 2502-3136 | e-ISSN: 2502-3128. Open Access at: http://lamlaj.ulm.ac.id/web/

\title{
PROSES PERALIHAN HAK MILIK ATAS TANAH KARENA PEWARISAN DALAM PERKAWINAN CAMPURAN
}

\author{
Muhammad Irvan ${ }^{1}$ Kurnia Warman ${ }^{2}$, Sri Arnetti ${ }^{3}$ \\ Program Magister Kenotariatan Fakultas Hukum Universitas Andalas \\ Jl.Pancasila No.10 Padang Telp.0751-27404, email.van.plur@gmail.com \\ Fakultas Hukum Universitas Andalas Jl. Pancasila No. 10 Padang \\ Telp/Fax.+62-751-27404, email.kwarman@law.unand.ac.id \\ Fakultas Hukum Universitas Andalas Jl. Pancasila No. 10 Padang \\ Telp/Fax: +62-751-27404, email.mkn.unand@gmail.com
}

Submitted : 09/09/2019 Reviewed 16/09/2019 Accepted:22/09/2019

\begin{abstract}
Land rights are rights giving authority to the right holder to use the and get the benefit from it.the rights holders is limited by the regulation. Those who may obtain property citizens only and legal entities indonesia based on government regulation. Ownership of the land is hereditary right, strongest and fullest that can be held above the land. But often the ownership of the land has created problems in the communities. One of them is due to the occurrence of a inter-marriage would have an impact on the property over the land for inheritance in marriage a mixture. The law which occurs because the inheritance which causes the transfer of ownership of land did not require nationality, but the provisions of land restrict the ownership of property for land gave it to transfer a land rights over land inherited by foreigners. Then problem identification discussed in research is as follows: (a) how the process of intermarriages according to marriage law? ( $b$ ) how the transition of ownership of the land because the inheritance in intermarriages? (c) how strong of property rights of the land because the inheritance in intermarriages? Research methodology used juridical approach is empirical research. Juridical empirical method, the research use approach to the problem, connected with the facts and law happens on the field. The research results show that the process was done based on marriage mingling law from the marriage was done. To ownership rights due to intermediate of the inheritance in marriage a mixture is the same with the transfer ownership rights as the other land inheritance. Along heir who performs marriage intervening who make a break to property by having them land rights. To the heirs who in marriage a mixture still heritage having land rights. If the heirs was for foreigners, they should release at most the due in a year time.
\end{abstract}


Keywords: Ownership of land; inheritance; intermarriage

\begin{abstract}
Abstrak: Hak atas tanah adalah hak yang memberikan wewenang kepada pemegang haknya untuk mempergunakan dan mengambil manfaat dari tanah yang dihakinya. Yang dapat mempunyai hak milik hanya WNI dan badan hukum Indonesia berdasarkan peraturan pemerintah. Hak milik adalah hak turun temurun, terkuat dan terpenuh yang dapat dipunyai orang atas tanah. Namun tidakjarang perolehan hak milik atas tanah tersebut menimbulkan permasalahan di tengah masyarakat. Salah satunya karena terjadinya perkawinan campuran yang akan berdampak terhadap perolehan hak milik atas tanah akibat pewarisan dalam perkawinan campuran. Peristiwa hukum yang terjadi karena pewarisan yang menyebabkan beralihnya hak milik atas tanah tidak mensyaratkan status kewarganegaraan, tetapi ketentuan peraturan agraria membatasi kepemilikan hak milik atas tanah memberi waktu untuk mengalihkan hak milik atas tanah yang diwarisi oleh warga negara asing. Maka identifikasi masalah yang dibahas dalam penelitian ini adalah sebagai berikut: (a) Bagaimanakah proses perkawinan campuran menurut hukum perkawinan? (b) Bagaimanakah peralihan hak milik atas tanah karena pewarisan dalam perkawinan campuran? (c) Bagaimanakah kedudukan hak milik atas tanah karena pewarisan dalam perkawinan campuran? Metode penelitian yang digunakan adalah pendekatan penelitian yuridis empiris. Metode yuridis empiris, yaitu suatu penelitian yang menggunakan pendekatan terhadap masalah, yang kemudian dihubungkan dengan fakta-fakta hukum yang terjadi di lapangan. Hasil penelitian menunjukkan bahwa proses perkawinan percampuran dilaksanakan berdasarkan hukum dari tempat perkawinan tersebut dilaksanakan. Terhadap peralihan hak milik atas tanah akibat pewarisan dalam perkawinan campuran adalah sama dengan peralihan hak milik has tanah akibat pewarisan lainnya. Sepanjang pewaris yang melakukan perkawinan campur yang melakukan perjanjian pisah harta dengan pasangannya untuk dapat memiliki hak atas tanah. Terhadap ahli waris yang dalam perkawinan campuran tetap dapat memiliki warisan berupa hak milik atas tanah. Apabila ahli waris tersebut merupakan WNA, maka ahli waris tersebut harus melepaskan haknya paling lama dalam waktu satu tahun.
\end{abstract}

Kata Kunci: Hak Milik Atas Tanah; Pewarisan; Perkawinan Campuran

\section{PENDAHULUAN}

Hak atas tanah adalah hak yang memberikan wewenang kepada pemegang haknya untuk mempergunakan dan mengambil manfaat dari tanah yang dihakinya. Subjek hukum hak atas tanah yaitu orang-orang dan badan hukum. Subjek hukum tersebut diberi kewenan- gan untuk mempergunakan tanah yang bersangkutan. Objek hak atas tanah meliputi permukaan dan tubuh bumi, air, dan ruang yang ada di atasnya dalam batas-batas tertentu. Pemegang hak atas tanah diberikan kewenangan untuk mempergunakan hak atas tanah, namun pemegang hak juga dibatasi haknya oleh Un- 
dang-Undang. Pembatasan itu meliputi:

a. Harus memperhatikan fungsi sosial;

b. Kepemilikan hak atas tanah tidak boleh melebihi maksimum dan minimum;

c. Yang dapat mempunyai hak milik hanya WNI dan badan hukum Indonesia berdasarkan peraturan pemerintah. ${ }^{1}$

Pembatasan hak tersebut sesuai dengan prinsip asas hukum agraria, yaitu hanya Warga Negara Indonesia yang mempunyai hak milik atas tanah. Ketentuan ini dapat dilihat dalam Pasal 9 ayat (1) yang menyatakan bahwa:

"Hanya Warga Negara Indonesia dapat mempunyai hubungan yang sepenuhnya dengan bumi, air dan ruang angkasa, dalam batas-batas pasal 1 dan pasal 2."

Hak milik atas tanah merupakan satu-satunya hak yang memiliki kedudukan terkuat dari jenis-jenis hak atas tanah lainnya. Hal ini terlihat dari Pasal 20 ayat (1) Undang-Undang Pokok Agraria yang menyatakan bahwa:

"Hak milik adalah hak turun temurun, terkuat dan terpenuh yang dapat dipunyai orang atas tanah, dengan mengingat ketentuan dalam Pasal 6." 2

Pada pasal tersebut dapat disimpulkan bahwa tanah yang didasarkan atas hak milik dapat dikuasai selama hidup pemiliknya dan dapat dilanjutkan kepemilikannya oleh ahli warisnya jika pemilik meninggal dunia, selama terpenuhinya ketentuan dan syaratsyarat yang mengatur tentang hak milik. Hak milik tidak mempunyai batas waktu dan memiliki kewenangan yang lebih luas dibandingkan hak-hak atas tanah lainnya. Hal ini sesuai dengan prinsip asas kebangsaan dalam

1 M. Arba. 2015. Hukum Agraria Indonesia. Jakarta:Sinar Grafika, hlm 85.

2 Boedi Harsono. 2002. Hukum Agraria Indonesia, Himpunan Peraturan-Peraturan Hukum Tanah, Edisi Revisi. Jakarta: Djambatan, hlm 12. hukum agraria di Indonesia, dimana hukum agraria mengutamakan kepentingan bangsa, dan hanya Warga Negara Indonesia yang berhak memiliki hak milik atas tanah.

Dilihat dari cara peralihannya, Pasal 20 ayat (2) UUPA menetapkan bahwa hak milik dapat beralih dan dialihkan kepada pihak lain. Bentuk peralihan hak milik atas tanah adalah sebagai berikut:

a. Beralih

Beralih artinya berpindahnya hak milik atas tanah dari pemiliknya kepada pihak lain disebabkan karena peristiwa hukum, yaitu meninggal dunianya pemilik tanah. Hal ini menjadikan hak milik atas tanah secara yuridis berpindah kepada ahli warisnya sepanjang ahli warisnya memenuhi syarat sebagai subjek hak milik.

b. Dialihkan

Dialihkan artinya berpindahnya hak milik atas tanah dari pemiliknya kepada pihak lain disebabkan oleh perbuatan hukum, yaitu perbuatan yang menimbulkan akibat hukum. Contoh dari perbuatan hukum tersebut adalah jual beli, tukar menukar, hibah, pemasukan dalam modal dalam perusahaan (inbreng), lelang. ${ }^{3}$

Beralihnya hak milik atas tanah akibat pewarisan merupakan sebuah peristiwa hukum. Ketentuan dalam pewarisan tidak mensyaratkan kewarganegaraan sebagai syarat untuk menjadi ahli waris, tetapi perolehan hak milik atas tanah memiliki syarat dan ketentuan yang membatasi perolehan hak milik atas tanah. Ketentuan tersebut diatur dalam Undang-Undang Pokok Agraria, sebagaimana yang disebutkan dalam Pasal berikut:

Pasal 21 ayat (1),

"Hanya Warga Negara Indonesia dapat

3 Urip Santoso. 2015. Perolehan Hak Atas Tanah. Jakarta: Prenadamedia Group., hlm 30. 
mempunyai hak milik."

Pasal 21 ayat (3),

"Orang asing yang sudah berlakunya Undang-Undang ini memperoleh hak milik karena pewarisan tanpa wasiat atau percampuran harta karena perkawinan, demikian pula Warga Negara Indonesia yang mempunyai hak milik dan setelah berlakunya undang-undang ini kehilangan kewarganegaraannya wajib melepaskan hak itu dalam jangka waktu satu tahun sejak diperolehnya hak tersebut atau hilangnya kewarganegaraan itu. Jika sesudah jangka waktu tersebut lampau hak milik itu tidak dilepaskan, maka hak tersebut hapus karena hukum dan tanahnya jatuh kepada negara, dengan ketentuan bahwa hak-hak pihak lain yang membebaninya tetap berlangsung."

Berdasarkan uraian pasal tersebut di atas dapat dilihat bahwa peraturan perundang-undangan di Indonesia membatasi dengan tegas terhadap perolehan hak atas tanah berupa hak milik. Ketentuan dalam peraturan perundangundangan agraria tidak menghapuskan hak sebagai ahli waris atas hak milik atas tanah yang diakibatkan oleh peristiwa hukum berupa pewarisan. Apabila syarat untuk memiliki hak milik tanah tidak terpenuhi, negara memberikan batas waktu terhadap ahli waris yang mewarisi hak milik atas tanah tersebut untuk melepaskan haknya kepada orang lain dalam jangka waktu 1 (satu) tahun.

Berdasarkan latar belakang permasalahan yang telah diuraikan di atas, maka identifikasi masalah yang dibahas dalam penelitian ini adalah sebagai berikut:

1. Bagaimanakah proses perkawinan campuran menurut hukum perkawinan?

2. Bagaimanakah proses peralihan hak mi- lik atas tanah karena pewarisan dalam perkawinan campuran?

3. Bagaimanakah kedudukan hak milik atas tanah karena pewarisan dalam perkawinan campuran?

\section{METODE}

Penelitian merupakan suatu sarana pokok dalam pengembangan ilmu pengetahuan maupun teknologi. Hal ini disebabkan, oleh karena penelitian bertujuan untuk mengungkapkan kebenaran secara sistematis, metodologis, dan konsisten. Melalui proses penelitian tersebut diadakan analisa dan konstruksi terhadap data yang telah disimpulkan dan diolah. ${ }^{4}$

Menurut Bambang Sunggono, penelitian pada dasarnya merupakan, "suatu upaya pencarian" dan bukannya sekedar mengamati dengan teliti terhadap sesuatu objek yang mudah terpegang di tangan. Penelitian merupakan terjemahan dari bahasa Inggris yaitu research, yang berasal dari kata re (kembali) dan to search (mencari). Dengan demikian secara logawiyah berarti "mencari kembali". 5

Metode penelitian yang penulis gunakan dalam penulisan tesis ini adalah sebagai berikut:

1. Pendekatan dan Sifat Penelitian

a. Pendekatan Masalah

Berdasarkan perumusan masalah dan tujuan penelitian, maka metode yang digunakan adalah pendekatan yuridis empiris. Metode yuridis empiris, yaitu suatu penelitian yang menggunakan pendekatan terhadap masalah, yang kemudian dihubungkan dengan fakta-fakta hukum yang terjadi di la-

4 Soerjono Soekanto dan Sri Mamudji. 1985. Penelitian Hukum Normatif, Suatu Tinjauan Singkat. Jakarta: PT RajaGrafindo Persada, hlm.1.

5 Bambang Sunggono. 1997. Metodologi Penelitian Hukum. Jakarta: PT Grafindo Persada, hlm. 27. 
pangan. Metode pendekatan yuridis empiris merupakan cara prosedur yang digunakan untuk memecahkan masalah penelitian dengan meneliti data sekunder terlebih dahulu untuk kemudian dilanjutkan dengan mengadakan penelitian terhadap data primer di lapangan, artinya metode pendekatan yuridis empiris ini mengkaji peraturan perundang-undangan yang terkait dan menghubungkannya dengan kenyataan kepemilikan hak atas tanah serta pewarisannya dalam perkawinan campuran.

b. Sifat penelitian Spesifikasi penelitian dalam penulisan tesis ini berupa penelitian hukum deskriptif analisis yaitu suatu penelitian yang menggambarkan, menelaah, menjelaskan, dan menganalisis suatu peraturan hukum baik dalam teori maupun praktek pelaksanaan dari hasil penelitian di lapangan. ${ }^{6}$

2. Jenis dan Sumber Data

Data - data yang diperlukan dalam penelitian ini adalah

a. Data primer

Data primer yaitu data yang langsung diperoleh dari lapangan dengan mengadakan wawancara dengan Badan Pertanahan Nasional.

b. Data sekunder

Data sekunder, yaitu bahan data yang diperoleh melalui penelitian kepustakaan yang berupa:

1) Bahan hukum primer yaitu bahan yang mempunyai kekuatan hukum mengikat bagi setiap individu atau masyarakat yang be- rasal dari peraturan perundangundangan, meliputi:

a) Kitab Undang-Undang Hukum Acara Perdata.

b) Undang-Undang Nomor 5 Tahun 1960 tentang Peraturan Dasar Pokok-Pokok Agraria.

c) Undang-Undang Nomor 1 Tahun 1974 tentang Perkawinan

d) Undang-Undang Nomor 12 Tahun 2006 tentang Kewarganegaraan Republik Indonesia.

2) Bahan hukum sekunder yaitu bahan yang berkaitan erat dengan bahan hukum primer dan dapat membantu menganalisa, memahami dan menjelaskan bahan hukum primer misalnya: buku-buku, jurnal, hasil seminar maupun teori tentang pembuatan pewarisan hak milik atas tanah dalam perkawinan campuran.

3) Bahan hukum tersier yakni bahan hukum yang dapat memberikan informasi, petunjuk dan penjelasan terhadap bahan hukum primer misalnya penggunaan kamus-kamus hukum

3. Teknik Pengumpulan Data

Pengumpulan data merupakan hal yang sangat erat hubungannya dengan sumber data, karena melalui pengumpulan data ini akan diperoleh data yang diperlukan untuk selanjutnya dianalisa sesuai dengan yang diharapkan. Metode pengumpulan data yang digunakan dalam penelitian ini adalah: 
a. Studi dokumen atau bahan kepustakaan adalah memperoleh data dengan mencari dan mempelajari buku-buku dan dokumen-dokumen yang berkaitan dengan peralihan hak milik atas tanah serta pewarisan hak milik atas tanah dalam perkawinan campuran.

b. Wawancara atau interview adalah dengan mengajukan pertanyaan-pertanyaan yang berhubungan dengan masalah yang diteliti oleh penulis kepada Badan Pertanahan Nasional mengenai peralihan hak milik atas tanah serta pewarisan hak milik atas tanah dalam perkawinan campuran

4. Pengolahan dan Analisis Data

Dalam penulisan karya tulis ini penulis melakukan, penganalisaan data dilakukan secara kualitatif. Analisa kualitatif adalah suatu analisa data yang dilakukan dengan cara menjelaskan data-data berdasarkan peraturan perundang-undangan yang berlaku, pendapat para ahli dan pengetahuan tentang peralihan hak milik atas tanah serta pewarisan hak milik atas tanah dalam perkawinan campuran.

\section{ANALISIS DAN PEMBAHASAN}

Salah satu permasalahan yang berkaitan dengan perolehan hak milik atas tanah akibat pewarisan dalam perkawinan campuran, penulis mencoba memasukkan contoh kasus yang berkaitan dengan hak waris anak yang telah diputus oleh Pengadilan, Putusan Nomor 141/G/2010/PTUN-JKT. Berawal dari Swita Motiram berkewarganegaraan Indonesia. yang menikah dengan suaminya yang berkewarganegaraan Inggris di Hongkong pada tahun 1979. Dalam penikahan tersebut Swita Motiram melepaskan kewarganegaraan Indonesia dan pindah menjadi warga negara
India. Dari perkawinan tersebut mereka memiliki seorang anak yang bernama Sunesh Rattan Ladharam yang lahir pada tahun 1982. Beberapa tahun setelah menikah Swita Motiram bercerai dengan suaminya pada tahun 1990, dan hak asuh anak dimenangkan oleh suaminya. Kemudian pada tahun 1990 Swita Motiram pindah dan menetap di Indonesia. Swita Motiram mengubah kewarganegaraannya menjadi warga negara Indonesia pada tahun1997. Pada tahun 2009, Swita Motiram meninggal dunia yang kemudian timbul masalah mengenai siapa yang berhak untuk menjadi ahli waris dari Swita Motiram terhadap hak milik atas tanah yang ada di Indonesia, dimana semenjak ia menetap di Indonesia Swita Motiram tidak pernah mencatatkan perkawinan, perceraian dan anak yang lahir dari perkawinan yang dilaksanakan di Hongkong tersebut.

\section{Proses Perkawinan Campuran Menurut Hukum Perkawinan}

Sebagaimana dimaksud dalam Pasal 57 Undang-undang Nomor 1 Tahun 1974 tentang Perkawinan, yang dimaksud dengan perkawinan campuran dalam undang-undang ini adalah perkawinan antara dua orang yang di Indonesia tunduk pada hukum yang berlainan karena perbedaan kewarganegaraan dan salah satu pihak berkewarganegaraan asing dan salah satu pihak berkewarganegaraan Indonesia. Perkawinan campuran dapat dilaksanakan di Indonesia dan dapat pula dilaksanakan di luar Indonesia (luar negeri).

Perkawinan campuran yang dilangsungkan di Indonesia dilaksanakan menurut UU Perkawinan, serta syarat-syarat untuk melaksanakan perkawinan yang berlaku menurut hukum masing-masing pihak (Pasal 60 ayat 
(1) UU Perkawinan). ${ }^{7}$ Perkawinan yang dilangsungkan di Indonesia harus memenuhi syarat-syarat perkawinan, diantaranya ada persetujuan kedua calon mempelai, izin dari kedua orangtua/wali bagi yang belum berumur 21 tahun, dan sebagainya (lihat pasal 6 UU Perkawinan). Apabila semua syarat telah terpenuhi, maka dapat meminta pegawai pencatat perkawinan untuk memberikan Surat Keterangan dari pegawai pencatat perkawinan masing-masing pihak, calon mempelai wanita dan calon mempelai pria, (pasal 60 ayat 1 UU Perkawinan). Surat Keterangan ini berisi keterangan bahwa benar syarat telah terpenuhi dan tidak ada rintangan untuk melangsungkan perkawinan.

Pencatatan Perkawinan bagi yang beragama Islam, pencatatan dilakukan oleh pegawai Pencatat Nikah atau Pembantu Pegawai Pencatat Nikah Talak Cerai Rujuk, sedangkan bagi yang Non Islam pencatatan dilakukan oleh Pegawai Kantor Catatan Sipil. Kutipan Akta Perkawinan yang telah didapatkan, masih harus dilegalisir di Departemen $\mathrm{Hu}-$ kum dan HAM dan Departemen Luar Negeri, serta didaftarkan di Kedutaan negara asal suami. Dengan adanya legalisasi itu, maka perkawinan yang sudah sah dan diterima secara internasional.

Perkawinan yang dilangsungkan di luar Indonesia antara dua orang Warga Negara Indonesia atau seorang Warga Negara Indonesia dengan Warga Negara Asing adalah sah bilamana dilakukan menurut hukum yang berlaku di negara dimana perkawinan itu dilangsungkan, dan bagi Warga Negara Indonesia tidak melanggar ketentuan UU Perkawinan. ${ }^{8}$

7 Abdulkadir Muhammad. 2000. Hukum Perdata Indonesia. Bandung: Citra Aditya Bakti, hlm. 114.

8 Hilman Hadikusuma. 1990. Hukum Perkawinan Indonesia Menurut Perundangan, Hukum Adat,
Bagi WNI yang akan melangsungkan pernikahannya di Luar Negeri harus menyampaikan kehendak nikahnya ke bagian konsuler Perwakilan RI di Luar Negeri. Penghulu di Luar Negeri harus memastikan bahwa berkas pemberitahuan kehendak nikah telah dipenuhi. Apabila calon pengantin WNI nya adalah seorang wanita hendaknya memastikan kehadiran wali atau surat wakalah wali yang diketahai oleh kepala KUA/Penghulu setempat di Indonesia dan dilegalisasi oleh pejabat yang membidangi kepenghuluan di Departemen Agama Pusat. Setelah pengumuman nikah dipampang selama sepuluh hari kerja maka akad nikah sudah boleh dilaksanakan. Pelaksanaan akad nikah kurang dari sepuluh hari kerja hanya dapat dilangsungkan oleh penghulu jika terdapat keadaan-keadaan mendesak, dan itupun harus memperoleh dispensasi dari Kantor Perwakilan RI di Negara setempat terlebih dahulu.

Prosesi akad nikah yang terlaksana di luar negeri sama saja dengan prosesi akad nikah yang ada di dalam negeri. Jika perkawinan campuran dilaksanakan di negara pihak lainnya itu, maka berlakulah ketentuan tentang tata cara menurut hukum di negara yang bersangkutan. Selama para pihak telah melaksanakan pencatatan perkawinan di luar negeri sesuai hukum yang berlaku di negara tempat perkawinan tersebut dilangsungkan, maka perkawinan adalah sah dengan segala akibat hukumnya. Namun, untuk sahnya perkawinan yang dilangsungkan di luar negeri tersebut menurut hukum Indonesia harus dilakukan pencatatan dan pelaporan pada Dinas Kependudukan dan Catatan Sipil di Indonesia dalam kurun waktu 1 (satu) tahun. ${ }^{9}$ Se-

Hukum Agama. Bandung: Mandar Maju, hlm. 20.

9 Irma Devita Purnamasari. 2011. Kiat-Kiat Cerdas, Mudah dan Bijak Memahami Masalah Hukum 
bagaimana diatur dalam Pasal 56 ayat 2 UU Perkawinan yang berbunyi:

"Dalam waktu 1 (satu) tahun setelah suami istri itu kembali di wilayah Indonesia surat bukti perkawinan mereka harus didaftarkan di Kantor Pencatatan Perkawinan tempat tinggal mereka”.

Apabila perkawinan terebut tidak dicatatkan di Indonesia, perkawinan tersebut dianggap tidak pernah ada. Hal ini pun diperkuat dengan Surat Edaran Mahkamah Agung No.3 tahun 2015 tentang Pemberlakuan Rumusan Hasil Rapat Pleno Kamar Makamah Agung Tahun Bagi Pengadilan yang berbunyi:

"Dalam hal terjadi perkawinan yang dilakukan di luar negeri yang tidak dicatatkan di Kantor Pencatat Perkawinan di Indonesia maka perkawinan itu dianggap tidak pernah ada."

Terhadap ketentuan seperti yang telah dijelaskan di atas, almarhumah Swita Motiram setelah ia menjadi Warga Negara Indonesia seharusnya melakukan pencatatan perkawinan, perceraian yang dilakukan di luar negeri (Hongkong), serta anak yang dilahirkan dalam perkawinan tersebut pada Kantor Pencatatan Perkawinan di Indonesia, agar anak dari Almarhumah Swita Motiram dapat diakui oleh hukum di Indonesia. Demikian jelas sudah bahwa dengan tidak didaftarkannya Sunesh Rattan Ladharam pada Kantor Pencatatan Perkawinan di Indonesia, meskipun ia sebagai anak dari Almarhumah Swita Motiram akan tetapi ia sebagai Warga Negara Asing, maka terhadapnya tidak bisa diberlakukan hukum yang berlaku di Indonesia.

\section{Peralihan Hak Milik Atas Tanah Karena} Pewarisan Dalam Perkawinan Campuran

Salah satu cara untuk memperoleh hak kebendaan dalam hukum perdata adalah melalui pewarisan. Hak kebendaan diperoleh berdasarkan pewarisan menurut hukum waris yang berlaku. Ada tiga macam hukum waris yang berlaku, yaitu hukum waris adat, hukum waris Islam dan hukum waris perdata. ${ }^{10}$

Hukum waris mengatur cara beralihnya hak-hak dan kewajiban-kewajiban atas harta kekayaan seseorang yang meninggal dunia kepada orang lain yang masih hidup. Dalam membicarakan hukum waris maka ada 3 hal yang perlu mendapat perhatian: ${ }^{11}$

a. Orang yang meninggal dunia, yang meninggalkan harta kekayaan;

b. Ahli waris yang berhak menerima harta kekayaan itu;

c. Harta kekayaan yang ditinggalkan oleh pewaris, dan yang akan beralih kepada ahli waris.

Anak yang lahir dalam perkawinan campuran yang berstatus WNI ataupun WNA, dapat memperoleh warisan berupa hak milik atas tanah. Dikarenakan pewarisan hak milik atas tanah tersebut merupakan peristiwa hukum. Jika anak yang dilahirkan dalam perkawinan campuran tersebut berkewarganegaraan asing, maka ahli waris tersebut harus melepaskan hak milik atas tanah tersebut dalam jangka waktu paling lama satu tahun. Apabila hak milik atas tanah tersebut tidak dilepaskan, maka tanah tersebut akan menjadi milik negara. $^{12}$

Dalam Putusan Pengadilan Nomor 141/G/2010/PTUN-JKT, dalam petimbangan hakim sesuai pasal $852 \mathrm{KUH}$ Perdata, Majelis Hakim sependapat bahwa setiap keturunan

10 Abdulkadir Muhammad, Op.Cit, hlm 140.

11 Ali Afandi. 1997. Hukum Waris Hukum Keluarga dan Hukum Pembuktian. Jakarta: Rineka Cipta, hlm 14.

12 Wawancara dengan Kepala Sub Seksi Peralihan Hak dan PPAT Pada Kantor Badan Pertanahan Nasional Kota Bukittinggi, Tanggal 1 Maret 2019. 
berhak mewarisi dari orang tuanya, namun dari ketentuan tersebut tidak ditemukan lembaga mana yang berhak mengeluarkan Surat Keterangan Hak Mewaris terhadap Warga Negara Asing yang orang tuanya Warga Negara Indonesia keturunan Timur Asing.

Peralihan hak karena pewarisan terjadi karena peristiwa hukum pada saat yang bersangkutan meninggal dunia. Sejak itu para ahli waris menjadi pemegang hak yang baru. Mengenai siapa yang menjadi ahli waris diatur dalam hukum perdata yang berlaku. Pendaftaran peralihan hak karena pewarisan juga diwajibkan dalam rangka memberikan perlindungan hukum kepada para ahli warisnya dan demi ketertiban tata usaha pendaftaran tanah. Surat tanda bukti sebagai ahli waris dapat berupa Akta Keterangan Hak Mewaris, atau Surat Penetapan Ahli Waris atau Surat Keterangan Ahli Waris. Sebagaimana dalam Peraturan Menteri Negara Agraria/ Keputusan Badan Pertanahan Nasional Republik Indonesia Nomor 3 Tahun 1997, Pasal 111 ayat (1) huruf c angka 4.

Peralihan hak karena pewarisan diatur dalam Pasal 42 Peraturan Pemerintah Nomor 24 Tahun 1997 tentang Pendaftaran Tanah, sebagai berikut:

1. Untuk peralihan hak karena pewarisan mengenai bidang tanah hak yang sudah terdaftar, wajib diserahkan oleh yang menerima hak atas tanah sebagai warisan kepada Kantor Pertanahan, sertipikat yang bersangkutan, surat kematian orang yang namanya dicatat sebagai pemegang haknya dengan surat tanda bukti sebagai ahli waris. Peralihan hak karena pewarisan terjadi karena hukum pada saat yang bersangkutan meninggal dunia. Dalam arti, bahwa sejak itu para ahi waris menjadi pemegang hak yang baru. Mengenai siapa yang menjadi ahli waris diatur dalam hukum perdata yang berlaku. Pendaftaran peralihan hak karena pewarisan juga diwajibkan dalam rangka memberikan perlindungan hukum kepada para ahli warisnya dan demi ketertiban tata usaha pendaftaran tanah. Surat tanda bukti sebagai ahli waris dapat berupa Akta Keterangan Hak Mewaris, atau Surat Penetapan Ahli Waris atau Surat Keterangan Ahli Waris.

2. Jika bidang tanah yang merupakan warisan belum didaftar, wajib diserahkan dokumen-dokumen surat keterangan Kepala Desa/ Kelurahan yang menyatakan orang bersangkutan menguasai tanah dan surat keterangan yang menyatakan bahwa bidang tanah tersebut belum bersertipikat dari Kantor Pertanahan atau surat keterangan Kepala Desa/ Lurah jika lokasi tanahnya jauh dari kedudukan Kantor Pertanahan dari pemegang hak yang bersangkutan. Dokumen yang membuktikan adanya hak atas tanah pada yang mewariskan diperlukan karena pendaftaran peralihan hak ini baru dapat dilakukan setelah pendaftaran untuk pertama kali atas nama pewaris.

3. Jika penerima waris terdiri dari satu orang, maka pendaftaran peralihan hak tersebut dilakukan kepada orang tersebut berdasarkan surat tanda bukti sebagai ahli waris seperti tersebut pada angka 1 di atas.

4. Jika penerima warisan lebih dari satu orang dan waktu peralihan hak tersebut didaftarkan disertai dengan akta pembagian waris yang memuat keterangan bahwa hak atas tanah jatuh kepada seorang penerima warisan tertentu, pendaftaran hak milik atas tanah dilakukan kepada 
penerima warisan yang bersangkutan berdasarkan suatu tanda bukti sebagai ahli waris dan akta pembagian waris tersebut. Dalam hal akta pembagian waris yang dibuat sesuai ketentuan yang berlaku dan harta waris jatuh pada seorang penerima warisan tertentu, pendaftaran peralihan haknya dapat langsung dilakukan tanpa alat bukti peralihan hak lain, misalnya akta Pejabat Pembuat Akta Tanah (PPAT).

5. Warisan berupa hak atas tanah yang menurut akta pembagian waris harus dibagi bersama antara beberapa penerima warisan atau waktu didaftarkan belum ada akta pembagian warisnya, didaftar peralihan haknya kepada para penerima waris yang berhak sebagai hak bersama mereka berdasarkan surat tanda bukti sebagai ahli waris dan / atau akta pembagian waris tersebut. ${ }^{13}$

Prosedur permohonan peralihan hak karena pewarisan Pasal 111 Peraturan Menteri Negara Agraria/ Keputusan Badan Pertanahan Nasional Nomor 3 Tahun 1997 tentang Peraturan Pelaksana Peraturan Pemerintah Nomor 24 Tahun 1997 tentang Pendaftaran Tanah menyebutkan bahwa:

(1) Permohonan pendaftaran peralihan hak atas tanah atau Hak Milik Atas Satuan Rumah Susun diajukan oleh ahli waris atau kuasanya dengan melampirkan:

a. Sertipikat hak atas tanah atau sertipikat Hak Milik Atas Satuan Rumah Susun atas nama pewaris, atau, apabila mengenai tanah yang belum terdaftar, bukti pemilikan sebagaimana dimaksud dalam Pasal 24 Peraturan Pemerintah Nomor 24 Tahun 1997;

13 Peraturan Pemerintah Republik Indonesia No. 24 tahun 1997., Penjelasan Pasal 42. b. Surat kematian atas nama pemegang hak yang tercantum dalam sertipikat yang bersangkutan dari Kepala Desa/Lurah tempat tinggal pewaris waktu meninggal dunia, rumah sakit, petugas kesehatan, atau intansi lain yang berwenang;

c. Surat tanda bukti sebagai ahli waris yang dapat berupa:

1) wasiat dari pewaris, atau

2) putusan Pengadilan, atau

3) penetapan hakim/Ketua Pengadilan, atau

4) bagi Warga Negara Indonesia penduduk asli: surat Keterangan ahli waris yang dibuat oleh para ahli waris dengan disaksikan oleh 2 (dua) orang saksi dan dikuatkan oleh Kepala Desa/ Kelurahan dan Camat tempat tinggal pewaris pada waktu meninggal dunia; bagi Warga Negara Indonesia keturunan Tionghoa: akta keterangan hak mewaris dari Notaris, bagi Warga Negara Indonesia keturunan Timur Asing lainnya: surat keterangan waris dari Balai Harta Peninggalan.

d. Surat kuasa tertulis dari ahli waris apabila yang mengajukan permohonan pendaftaran peralihan hak bukan ahli waris yang bersangkutan;

e. Bukti identitas ahli waris;

(2) Apabila pada waktu permohonan pendaftaran peralihan sudah ada putusan pengadilan atau penetapan hakim/ Ketua Pengadilan atau akta mengenai pembagian waris sebagaimana dimaksud Pasal 42 ayat (4) Peraturan Pemerintah Nomor 24 Tahun 1997, maka putusan/ penetapan atau akta tersebut juga dilampirkan pada 
permohonan sebagaimana dimaksud pada ayat (1).

(3) Akta mengenai pembagian waris sebagaimana dimaksud pada ayat (2) dapat dibuat dalam bentuk akta dibawah tangan oleh semua ahli waris dengan disaksikan oleh 2 orang saksi atau dengan akta notaris.

(4) Apabila ahli waris lebih dari 1 (satu) orang dan belum ada pembagian warisan, maka pendaftaran peralihan haknya dilakukan kepada para ahli waris sebagai pemilikan bersama, dan pembagian hak selanjutnya dapat dilakukan sesuai ketentuan Pasal 51 Peraturan Pemerintah Nomor 24 Tahun 1997.

(5) Apabila ahli waris lebih dari 1 (satu) orang dan pada waktu pendaftaran peralihan haknya disertai dengan akta pembagian waris yang memuat keterangan bahwa hak atas tanah atau Hak Milik atas Satuan Rumah Susun tertentu jatuh kepada 1 (satu) orang penerima warisan, maka pencatatan peralihan haknya dilakukan kepada penerima warisan yang bersangkutan berdasarkan akta pembagian waris tersebut.

(6) Pencatatan pendaftaran peralihan hak sebagaimana dimaksud Pasal ini dalam daftar pendaftaran tanah dilakukan sebagaimana dimaksud dalam Pasal 105. ${ }^{14}$

Dengan peralihan hak dimaksudkan oleh para pihak adalah untuk memindahkan hak dari satu pihak ke pihak yang lain. Pihak yang menerima hak akan memperoleh hak dalam status asal, tanpa perubahan dan untuk waktu selama-lamanya. Dengan jatuhnya tanah kepada ahli waris, terjadilah pemilikan bersama

14 Peraturan Menteri Negara Agraria/ Keputusan Badan Pertanahan Nasional Nomor 3 Tahun 1997., Pasal 111. tanah hak milik jika tanah tersebut hanya satu satunya, jika pewaris memiliki tanah tersebut sesuai dengan jumlah ahli waris dan telah dibuatkan surat wasiat, maka tanah dimaksud telah menjadi milik masing-masing ahli waris. Jatuhnya harta warisan dari pemegang hak atas tanah kepada ahli waris bukan karena suatu perbuatan hukum, melainkan berpindah karena peristiwa hukum. ${ }^{15}$

Dilihat dari Putusan Pengadilan Nomor 141/G/2010/PTUN-JKT, dalam petimbangan hakim sesuai pasal 852 KUH Perdata, Majelis Hakim sependapat bahwa setiap keturunan berhak mewarisi dari orang tuanya, namun dari ketentuan tersebut tidak ditemukan lembaga mana yang berhak mengeluarkan Surat Keterangan Hak Mewaris terhadap Warga Negara Asing yang orang tuanya Warga Negara Indonesia keturunan Timur Asing. Berdasarkan putusan tersebut, artinya Sunesh Rattan Ladharam sebagai warga negara asing dapat mewaris tanpa wasiat, namun ia dalam jangka waktu 1 (satu) tahun harus melepaskan hak milik atas tanah tersebut. Pelepasan hak dapat dilakukan dengan menjual hak milik yang diperolehnya kepada pihak lain yang dapat memiliki hak milik atas tanah sesuai dengan ketentuan hukum agraria di Indonesia.

\section{Kedudukan Hak Milik Atas Tanah Ka- rena Pewarisan Dalam Perkawinan Cam- puran}

Peralihan hak atas tanah dapat melalui jual beli, tukar menukar, hibah ataupun karena pewarisan. Dalam Pasal 26 ayat (1) UndangUndang Pokok Agraria menjelaskan bahwa jual beli, penukaran, penghibahan, pemberian dengan wasiat, dan perbuatan-perbuatan lain yang dimaksudkan untuk pemindahan hak milik serta pengawasannya diatur dengan

\footnotetext{
15 Urip Santoso. 2005. Hukum Agraria dan Hak-Hak Atas Tanah. Jakarta: Kencana, hlm 398.
} 
Peraturan Pemerintah. ${ }^{16}$

Perolehan hak lazimnya terjadi karena pemindahan hak secara khusus atau satu persatu dari seorang kepada orang lain, misalnya karena jual beli, pemberian, pertukaran dan sebagainya. Namun ada juga perolehan hak secara umum, tidak memakai perincian satu persatu. Hal ini terjadi pada suatu pewarisan atau perkawinan dengan percampuran kekayaan. Seorang ahli waris mendapat seluruh atau sebagian dari semua hak si meninggal. Seorang isteri yang kawin dalam percampuran kekayaan memperoleh separuh dari semua hak-hak suaminya. ${ }^{17}$

Akibat hukum dari peralihan hak tersebut, maka seseorang akan kehilangan hak terhadap sesuatu benda, dan orang lain mendapatkan hak tersebut karena sesuatu hal sebagaimana yang dijelaskan, yakni dapat melalui jual beli, warisan, pemberian, wasiat dan sebagainya. Suatu benda milik seseorang kemudian dialihkan hak miliknya kepada orang lain melalui hal-hal tersebut di atas, maka orang yang bersangkutan tidak dapat lagi menguasai benda tersebut, karena hak miliknya sudah beralih kepada orang lain. ${ }^{18}$

Dalam pasal 58 Undang-Undang Perkawinan ditetapkan bagi orang-orang yang berlainan kewarganegaraan yang melakukan perkawinan campuran, dapat memperoleh kewarganegaraan suami/ istrinya dan dapat pula kehilangan kewarganegaraannya, menurut cara-cara yang telah ditentukan dalam Undang-Undang Kewarganegaraan Republik Indonesia. Kedudukan anak dalam hal ke-

16 Andrian Sutedi. 2006. Peralihan Hak Atas Tanah Dan Pendaftarannya. Jakarta: Sinar Grafika, hlm 3.

17 Subekti. 2001. Pokok-Pokok Hukum Perdata. Jakarta: Intermasa, hlm 73.

$18 \quad$ Ibid., hlm 74. warganegaraan, anak yang belum berumur 18 tahun dan belum kawin yang mempunyai hubungan kekeluargaan dengan ayahnya memperoleh status kewarganegaraan ayahnya (pasal 13 Undang-Undang Kewarganegaran Republik Indonesia). ${ }^{19}$

Terhadap WNI yang melakukan perkawinan campuran dengan WNA, tetap dapat memiliki hak milik atas tanah sepanjang WNI tersebut tidak melepaskan kewarganegaraannya mengikuti kewarganegaraan suami atau istrinya, juga sepanjang WNI yang melakukan perkawinan campuran tersebut melakukan perjanjian kawin terhadap pemisahan harta kekayaan. Apabila WNI yang melakukan perkawinan campuran tersebut berdomisili di luar negeri, dapat menunjukkan bukti kewarganegaraannya melalui paspor yang dimilikinya. ${ }^{20}$

Menyangkut status anak yang lahir dari pasangan kawin campur diatur dalam Pasal 59 ayat (1) Undang-Undang Perkawinan, kewarganegaraan si anak yang diperoleh sebagai akibat perkawinan atau putusnya perkawinan orang tuanya menentukan hukum yang berlaku, baik mengenai hukum publik maupun hukum perdata. Kewarganegaraan anak yang lahir dalam perkawinan campuran akan menentukan terhadap hak milik atas tanah yang akan diwarisinya nanti.

Kedudukan hak milik atas tanah yang diperoleh akibat pewarisan dalam perkawinan campuran adalah sama dengan kedudukan hak milik atas tanah yang dimiliki oleh WNI, sepanjang ahli waris yang menerima warisan hak milik atas tanah tersebut merupakan seorang WNI. Bahkan jika ahli waris tersebut berdomisili di luar negeri dapat memiliki hak milik atas tanah tersebut dapat menunjukkan

19 Ibid., hlm 140.

20 Wawancara BPN, Op.Cit. 
paspor kewarganegaraan Indonesia. ${ }^{21}$

Berdasarkan uraian di atas, dapat diartikan bahwa kedudukan hak milik atas tanah karena pewarisan dalam perkawinan campuran mempunyai kekuatan hukum yang sah apabila telah memenuhi segala ketentuan dan syarat-syarat yang telah ditentukan oleh undang-undang dan peraturan lainnya. Sepanjang telah terjadi perjanjian kawin terhadap pemisahan harta dalam perkawinan campuran. Dimana hak milik atas tanah tersebut diwariskan kepada ahli waris yang mempunyai kewarganegaraan Indonesia.

\section{PENUTUP}

\section{Kesimpulan}

a. Proses perkawinan campuran dilaksanakan menurut undang-undang yang berlaku. Jika perkawinan campuran tersebut dilangsungkan di luar negeri, maka proses perkawinan tersebut dilaksanakan sesuai ketentuan tempat dimana perkawinan campuran tersebut dilaksanakan. Begitu juga jika perkawinan tersebut dilangsungkan di Indonesia, maka dilaksanakan sesuai undang-undang yang berlaku di Indonesia. Terhadap perkawinan campuran yang dilakukan di luar negeri harus segera melakukan pencatatan perkawinan tersebut sekembalinya ke Indonesia agar perkawinan tersebut dapat diakui oleh peraturan yang berlaku di Indonesia.

b. Proses peralihan hak milik atas tanah akibat pewarisan dalam perkawinan campuran adalah sama dengan peralihan hak milik has tanah akibat pewarisan lainnya. Peralihan hak milik atas tanah karena pewarisan merupakan sebuah peristiwa hukum, dan hukum waris tidak mensyaratkan batas kewarganegaraan terha-

21 Wawancara BPN, Op.Cit. dap peristiwa hukum dalam pewarisan. Akan tetapi ketentuan dalam peraturan agraria memberi batasan bahwa hanya Warga Negara Indonesia yang boleh memiliki hak milik atas tanah.

c. Kedudukan hak milik atas tanah yang diperoleh akibat pewarisan dalam perkawinan campuran adalah sama dengan kedudukan hak milk lainnya, karena pewarisan adalah peristiwa hukum. Terhadap ahli waris yang dalam perkawinan campuran tetap dapat memiliki warisan berupa hak milik atas tanah. Namun jika ahli waris tersebut merupakan WNA, maka ahli waris tersebut harus melepaskan haknya paling lama dalam waktu satu tahun. Apabila hak tersebut tidak dilepaskan dalam jangka waktu 1 (satu) tahun, maka hak atas tanah tersebut menjadi milik negara.

\section{Saran}

Agar pasangan yang melakukan perkawinan campur untuk dapat melaksanakan perkawinan sesuai dengan peraturan yang berlaku, Di dalam perkawinan tersebut sebaiknya melakukan perjanjian kawin agar tidak kehilangan haknya untuk memperoleh hak milik atas tanah. Terhadap ahli waris yang mewarisi hak milik atas tanah dalam perkawinan campuran agar dapat mematuhi ketentuan yang mengatur tentang kepemilikan hak milik atas tanah, yaitu Undang-undang Nomor 5 tahun 1960 tentang Undang-undang Pokok Agraria.

\section{BIBLIOGRAFI}

Afandi, Ali. 1997. Hukum Waris Hukum Keluarga dan Hukum Pembuktian. Jakarta: Rineka Cipta.

Muhammad, Abdulkadir. 2000. Hukum Perdata Indonesia. Bandung: Citra Aditya Bakti 
Sutedi, Andrian. 2006. Peralihan Hak Atas Tanah Dan Pendaftarannya. Jakarta: Sinar Grafika.

Sunggono, Bambang. 1997. Metodologi Penelitian Hukum. Jakarta: PT Grafindo Persada.

Harsono, Boedi. 2002. Hukum Agraria Indonesia. Himpunan Peraturan-Peraturan Hukum Tanah, Edisi Revisi. Jakarta: Djambatan.

Soekanto, Soerjono dan Sri Mamudji, 1985. Penelitian Hukum Normatif, Suatu Tinjauan Singkat. Jakarta: PT Raja Grafindo Persada.

Hadikusuma, Hilman. 1990. Hukum Perkawinan Indonesia Menurut Perundangan, Hukum Adat, Hukum Agama. Bandung: Mandar Maju.
Purnamasari, Irma Devita. 2011. Kiat-Kiat Cerdas, Mudah dan Bijak Memahami Masalah Hukum Pertanahan. Jakarta: Kaifa.

Arba, M. 2015. Hukum Agraria Indonesia. Jakarta:Sinar Grafika.

Subekti. 2001. Pokok-Pokok Hukum Perdata. Jakarta: Intermasa.

Santoso, Urip. 2005. Hukum Agraria dan Hak-Hak Atas Tanah, Jakarta: Kencana.

Santoso, Urip. 2015. Perolehan Hak Atas Tanah. Jakarta: Prenadamedia Group. 